\title{
Oviduct Epithelial Cell Co-culture of early Porcine Embryos
}

\author{
By S. Smith, M. Schmidt, B. Purwantara and T. Greve \\ Department of Clinical Studies, Reproduction, Royal Veterinary and Agricultural University Frederiksberg, \\ Denmark.
}

\begin{abstract}
Smith, S., M. Schmidt, B. Purwantara and T. Greve: Oviduct epithelial cell co-culture of early porcine embryos. Acta vet. scand. 1992, 33, 349-355. - One- to 16-cell porcine embryos were cultured in either Whittens medium supplemented with bovine serum albumin and fetal calf serum (WM) or in the same medium with porcine oviduct epithelial cell co-culture (WM-Poec). All stages of embryos cultured in WM-POEC had higher cell counts after 144-168 h of development than did embryos in WM. There was however, no significant difference in blastocyst formation rate of embryos cultured in WM-POEC over those cultured in WM. A high proportion of the embryos entering culture at the 1-2-cell were able to pass the 4-cell block stage in both WM and WM-POEC, $81 \%$ and $77 \%$, respectively. In both media, most of the 1-2-cell embryos arrested their development at the compacted morula stage and failed to blastulate while embryos initiating culture at the 4-and 8-16-cell embryos formed blastocysts in culture at a rate of $80-90 \%$.
\end{abstract}

pig; oviduct epithelium.

\section{Introduction}

Interest in experimental procedures such as nuclear transplantation, gene transfer and in vitro fertilization in farm animal species has helped spur research into requirements for successful culture of the early embryonic stages (Bavister, 1988). In recent years the use of oviductal cells and their secretions have yielded vastly improved developmental rates when culturing early embryos in sheep (Gondolfi and Moor, 1987, Rexroad and Powell, 1988) and cattle (Eyestone and First, 1989, Ellington et al. 1990).

Advances in the culture methods for early stage porcine embryos in defined media supplemented with an oviductal component have also been encouraging. Embryos have been cultured from the 1- or 2-cell stage, through the 4-cell developmental block, resulting in a high rate of development to blastocysts. This has been achieved by using culture systems based upon a variety of commonly used embryo culture media that are supplemented with either oviductal fluid (Archibong et al. 1989) or by co-culturing with oviduct epithelial cells (White et al. 1989). The results obtained are comparable with recent reports of the culture of 1-cell pig embryos in mouse oviduct explants (Krishner et al. 1989a, Krishner et al. 1989b). They have the added advantage that the embryos are not sequestered, as they are in the mouse oviduct explant or in an intermediate recipient, and therefore can be monitored at will under the microscope. There is also the consideration of the labor and expense of using intermediate recipients as well as the embryo 
losses that inevitably occur when additional manipulations are performed.

The objective of the present study was to evaluate the ability of a primary culture of porcine oviduct epithelial cells to promote the development of early embryonic stages (1- to 16-cell) of porcine embryos when cultured in vitro. Included in this is an evaluation of the passage of the socalled in vitro 4cell developmental block by 1- and 2-cell embryos when cultured in vitro.

\section{Materials and methods}

Prepuberal Landrace-Yorkshire (LxY) cross gilts $(n=21)$ were synchronized and superovulated with a gonadotrophin treatment consisting of 1200 i.u. PMSG (Antex, Leo Pharmaceuticals, Denmark) followed in $72 \mathrm{~h}$ by 750 i.u. HCG (Physex, Leo Pharmaceuticals, Denmark). Gilts were artificially inseminated twice at approximately 36 and $48 \mathrm{~h}$ after the HCG injection. Embryos (1- to 16cell) were surgically collected between 51 and $138 \mathrm{~h}$ after HCG injection. Anesthesia was induced and maintained with intravenous pentobarbital (Leopental; Leo Pharmaceuticals, Denmark) at $10-15 \mathrm{mg} / \mathrm{kg}$. The uterus was exposed via a ventral midline incision and a $4.7 \mathrm{~mm}$ balloon catheter (NortaBeierdorf, Hamburg) was introduced into the lumen and the cuff inflated. A blunt tipped catheter was placed into the ostium of the oviduct and $2 \times 20 \mathrm{ml}$ of warmed Dulbeccos phosphate buffered saline (PBS) containing 1\% Fetal Calf Serum (FCS) was flushed through the tract and collected via the balloon catheter into a $10 \mathrm{~cm}$ sterile petridish. One- and 2-cell embryos were flushed from the oviduct and collected at the uterotubal junction while the more advanced stages were collected about $20 \mathrm{~cm}$ distal to this point. Embryos were isolated under a stereomicroscope at $50 \mathrm{X}$. The criterion used for confirmation of fertilization in embryos was that multiple sperm heads were observed in the zona pellucida. Following isolation the embryos were submitted to in vitro culture. Porcine oviduct epithelial cells (POEC) were harvested from gonadotrophin treated gilts on day 1 after estrus. The oviducts were flushed twice as described and the fluid collected at the uterotubal junction. Embryos were recovered from the first flush. The second flush was collected into a sterile tube and the oviduct cells were washed $2 X$ by centrifugation at $500 \mathrm{~g}$ for $5 \mathrm{~min}$. Finally, the pellet was resuspended in $1.0 \mathrm{ml}$ of culture medium. Ten $\mu \mathrm{l}$ of POEC suspension containing sheets of cells and possessing vigorous ciliary activity were pipetted into $40 \mu \mathrm{l}$ droplets of culture media under sterile paraffin oil.

Two different culture systems were evaluated to determine their ability to promote development of early cleavage stage embryos. Embryos were cultured either in Whitten's medium (Whitten \& Biggers, 1988) supplemented with $4 \mathrm{mg} / \mathrm{ml}$ fraction $\mathrm{V}$ bovine serum albumin (BSA, Sigma) and 10\% FCS (WM) or the same medium and supplements plus fresh POEC suspension (WM-POEC). Embryos were cultured in $50 \mu \mathrm{l}$ droplets of culture medium under paraffin oil at $39^{\circ} \mathrm{C}$ in a $5 \% \quad \mathrm{CO}_{2}$ and $100 \%$ humidified air atmosphere. Embryos were evaluated every $12 \mathrm{~h}$ to monitor development. All embryos were removed from culture at $144-168 \mathrm{~h}$ after the expected time of ovulation which was estimated to be $42 \mathrm{~h}$ after the HCG injection (Pope et al. 1988).

Embryos were evaluated for morphological development under an inverted microscope at $320 \mathrm{X}$. Cell counts were made by staining embryos with the fluorescent bisbenzimidazole stain Hoechst 33342 (Sigma) after the methods described by Pursel (Pursel et al. 
1985). The specimens were examined on a Zeiss IM 35 microscope under epifluorescence using an exication filter UG $1(365 \mathrm{~nm})$ and a barrier filter $41(410 \mathrm{~nm})$.

Analysis of variance was done with the SAS program (SAS Inst. Inc.) using the general linear model (GLM).

\section{Results}

The culture media tested were able to support development of 1- and 2-cell embryos past the 4-cell in vitro developmental block at nearly the same rates, $81 \%$ and $77 \%$ for WM and WM-POEC, respectively. While most of these embryos proceded to form compact morulae $(57 \%$ and $41 \%$ for WM and WM-POEC, respectively) few of them developed into blastocysts (Table 1).
The rate of blastocyst formation for embryos cultured in WM was $14 \%, 83 \%$ and $80 \%$ for 1-2-cell, 4-cell, and 8-16-cell stages, respectively (Table 2). The rate of blastocyst formation for embryos cultured in WM-POEC was $18 \%, 90 \%$, and $89 \%$ for $1-2$-cell, 4 -cell, and 8-16-cell stages, respectively (Table 2). The differences for within stage development of embryos into blastocysts between the 2 culture media were not significant. However, both the 4-cell and 8- to 16-cell stages developed into blastocysts at a significantly higher rate than did 1 - to 2 -cell embryos $(\mathrm{p}<0.001$ and $\mathrm{p}<0.001$, respectively, table 2 ).

The mean nuclei counts of embryos that formed blastocysts were higher for all stages of embryos cultured in WM-POEC than for in WM (Table 3). When all stages of embryos

Table 1. Development of 1-cell and 2-cell embryos in WM and WM-POEC after $144 \mathrm{~h}^{\mathrm{a}}$.

\begin{tabular}{lcccc}
\hline \multirow{2}{*}{ Medium } & \multicolumn{4}{c}{ Developmental Stage } \\
\cline { 2 - 5 } & $\begin{array}{c}\text { Number } \\
\text { 1-cell/2-cell }\end{array}$ & $\begin{array}{c}>\text { 4-Cell } \\
\text { Stage (\%) }\end{array}$ & $\begin{array}{c}\text { Compact } \\
\text { Morulae (\%) }\end{array}$ & $\begin{array}{c}\text { Blastocysts } \\
(\%)\end{array}$ \\
\hline WM & $10 / 11$ & $17(81)$ & $12(57)$ & $3(14)$ \\
WM-POEC & $10 / 12$ & $17(77)$ & $9(41)$ & $4(18)$ \\
\hline
\end{tabular}

${ }^{\mathrm{a}}$ time $0=42 \mathrm{~h}$ post $\mathrm{HCG}$.

Table 2. Development and cell counts of all embryos in WM or WM-POEC after 144-168 $\mathrm{h}^{\mathrm{a}}$.

\begin{tabular}{|c|c|c|c|c|c|c|}
\hline \multirow[b]{3}{*}{$\begin{array}{l}\text { Initial } \\
\text { Stage }\end{array}$} & \multicolumn{6}{|c|}{ Culture Media } \\
\hline & \multicolumn{3}{|c|}{ WM } & \multicolumn{3}{|c|}{ WM-POEC } \\
\hline & $\mathbf{N}$ & $\begin{array}{c}\mathrm{BL} \\
(\%)\end{array}$ & $\begin{array}{l}\text { Cell Count } \\
(\mathrm{M} \pm \mathrm{SEM})\end{array}$ & $\mathrm{N}$ & $\begin{array}{c}\mathrm{BL} \\
(\%)\end{array}$ & $\begin{array}{c}\text { Cell Count } \\
(\mathrm{M} \pm \mathrm{SEM})\end{array}$ \\
\hline 1-2-cell & 21 & $3(14)$ & $13.7 \pm 3.3^{c}$ & 22 & $4(18)$ & $13.8 \pm 3.8^{c}$ \\
\hline 4-cell & 30 & $25(83)$ & $54.9 \pm 5.3^{\mathrm{d}}$ & 31 & $28(90)$ & $67.1 \pm 6.4^{d}$ \\
\hline 8-16-cell & 20 & $16(80)$ & $64.6 \pm 7.8^{\mathrm{d}}$ & 18 & $16(89)$ & $77.5 \pm 9.4^{d}$ \\
\hline 4-16-cell ${ }^{b}$ & 50 & $41(82)$ & $58.1 \pm 4.4^{\mathrm{d}, \mathrm{e}}$ & 49 & 44 (89) & $70.9 \pm 5.3^{\mathrm{d}, \mathrm{f}}$ \\
\hline
\end{tabular}

a: time $0=42 \mathrm{~h}$ post $\mathrm{HCG} ; \mathrm{BL}=$ blastocysts;

b: pooled data.

$c, d$ : values in same column with different superscripts differ significantly $(p<0.001)$.

$\mathrm{e}, \mathrm{f}$ : values in same row with different superscripts differ $(\mathrm{p}<0.07)$. 
Table 3. Cell counts of blastocysts cultured in WM or WM-POEC after 144-168 h of edevelopment ${ }^{\mathrm{a}}$.

\begin{tabular}{|c|c|c|c|c|}
\hline \multirow[b]{3}{*}{$\begin{array}{l}\text { Initial } \\
\text { Stage }\end{array}$} & \multicolumn{4}{|c|}{ Culture Media } \\
\hline & \multicolumn{2}{|c|}{ WM } & \multicolumn{2}{|c|}{ WM-POEC } \\
\hline & $\begin{array}{c}\mathrm{N} \\
\mathrm{BL}\end{array}$ & $\begin{array}{l}\text { Cell Count } \\
(\mathrm{M} \pm \mathrm{SEM})\end{array}$ & $\begin{array}{l}\mathrm{N} \\
\mathrm{BL}\end{array}$ & $\begin{array}{l}\text { Cell Count } \\
(\mathrm{M} \pm \mathrm{SEM})\end{array}$ \\
\hline 1-2-cell & 3 & $36.0 \pm 18.1^{\mathrm{c}}$ & 4 & $44.3 \pm 21.7^{\mathrm{c}}$ \\
\hline 4-cell & 25 & $63.6 \pm 4.7^{d}$ & 28 & $72.0 \pm 6.4^{\mathrm{d}}$ \\
\hline 8-16-cell & 16 & $67.2 \pm 7.7^{\mathrm{d}}$ & 16 & $84.8 \pm 8.9^{d}$ \\
\hline 4-16-cell ${ }^{b}$ & 41 & $64.3 \pm 4.3^{\mathrm{d}, \mathrm{e}}$ & 44 & $76.6 \pm 5.2^{\mathrm{d}, \mathrm{f}}$ \\
\hline
\end{tabular}

a: time $0=42 \mathrm{~h}$ post $\mathrm{HCG} ; \mathrm{BL}=$ blastocysts;

b: pooled data.

c,d: values with different superscripts within the same column differ significantly $(\mathrm{p}<0.001)$.

$\mathrm{e}, \mathrm{f}$ : values in same row with different superscripts differ $(\mathrm{p}<0.06)$.

entering culture at the 4- to 16-cell stages were pooled the mean nuclei numbers of blastocysts were $64.3 \pm 4.3$ for culture in WM and $76.6 \pm 5.2$ for embryos cultured in WMPOEC ( $<<0.06$, Table 3$)$.

The POEC retained ciliary activity for up to a week after introduction into the droplet. For the most part they remained attached in large sheetlike aggregates of epithelia up to $1.0 \mathrm{~mm}$ long. Some of the cells became disattached from the aggregates. Within 1 or 2 days these cells attached to the culture plate and began to form colonies which became $40-50 \%$ confluent monolayers within 4-5 days.

\section{Discussion}

The results showed a consistent pattern for all embryo stages cultured in that POEC coculture did not elicit a significantly higher rate of passage to more developed stages than did culture in medium alone. It did, however, promote an increased overall cleavage rate in embryos, and the differences were significant for the more advanced embryos entering culture (4-, 8- and 16-cell). The failure of POEC co-culture to show a greater difference in rate of blastocyst forma- tion in the 4- to 16-cell embryos than culture media is understandable. WM alone supported an $81 \%$ blastocyst rate while co-cultured embryos did so at $90 \%$ and there was little room for improvement.

However, the results of culturing 1- to 2-cell embryos are equivocal. While 1- and 2-cell embryos were able to pass the 4-cell stage developmental block quite readily, very few formed blastocysts regardless of the culture system employed. For both culture systems tested the single largest group of embryos $(49 \%)$ ceased development at the compact morula stage and $16 \%$ proceded to form blastocysts. Rather than encountering an in vitro 4-cell stage block in development we saw a block at the compact morula stage. While we believe that this was probably due to a deficiency of the culture media or conditions it is interesting that these embryos, by and large, were able to undergo compaction but reletively few were capable of blastocoel formation.

That oviductal cell co-culture of embryos did not support a greater degree of blastocyst formation of the 1- and 2-cell embryos is in contrast to a study in pigs (White et al. 1989) where 2-cell embryos were cultured in modi- 
fied Eagles medium with $10 \%$ FCS, $5 \mathrm{mg} / \mathrm{ml}$ BSA and oviductal cells and $62 \%$ developed into blastocysts. Another study used modified Krebs Ringer Bicarbonate supplemented with oviductal fluid collected from sows on days 1-5 after estrus to culture 1-2-cell embryos (Archibong et al. 1989). Using this system they saw a $64 \%$ development of these stages into blastocysts opposed to a $27 \%$ developmental rate of embryos in culture media alone.

The benefit of oviductal cell co-culture has been reported in other species as well including sheep (Gandolfi and Moor, 1987, Rexroad and Powell, 1988), and cattle (Eyestone and First, 1989, Ellington et al. 1990). These studies have shown that oviductal cell co-culture has a significant effect in promoting blastocyst formation of pre-block stage embryos over culture media alone. A possible specific effect of oviduct cell coculture has been suggested (Gandolfi et al. 1989). They found that in sheep, oviduct epithelial cells secret two specific proteins $(46 \mathrm{kD}$ and $92 \mathrm{kD})$ on the day of heat which bind to the zona pellucida and plasma membrane of embryos as they transit the oviduct. They also found that in vitro cultured oviductal cells secrete the same proteins and that presumably these may play a role in supporting the development of cultured embryos. At this time a specific embryotrophic factor in porcine oviductal cells has not been identified. Besides possibly providing specific embryotrophic factors oviductal cells may also impart general support to embryos by altering the physio-chemical environment such as with $\mathrm{pH}$ or gas tension (Bavister 1988).

Although we had expected POEC co-culture to improve the development of 1- and 2-cell embryos compared to culture in media alone it was found that there was no difference in their development. We have considered various reasons for this.

Embryos from gonadotrophin stimulated gilts as well as prepuberal gilts do not develop in vitro as well as those from mature gilts or sows. Menino and co-workers (1987) reported that 1- and 2-cell embryos from first estrous gilts (unstimulated) do not develop in vitro as well as those from third estrous gilts. Another group found that 1- and 2-cell embryos from gonadotrophin stimulated prepuberal gilts have an inferior capacity for in vitro development than do embryos from mature gilts (Pinkert et al. 1989, Kooyman et al. 1988). However, when White and coworkers (1989) tested POEC co-culture on gonadotrophin treated prepuberal gilts on 2cell embryos they achieved a $62 \%$ blastocyst formation. Furthermore, they harvested oviduct cells from gonadotrophin stimulated gilts and treated the cells very similarly as was done in the present study.

Another possibility for the lack of continued development of the 1- and 2-cell embryos is that the culture media contained inhibitory factors or alternatively that the media were deficient in some factor(s) required for normal development (including cavitation and blastocoel expansion). If a detrimental component were present in the medium it is one that oviduct cell co-culture is not capable of mitigating because the development of cocultured embryos was remarkably similar to that of embryos in the media alone. Pyruvate, a component of the Whitten's medium used in this experiment, has been reported to be detrimental to development of porcine embryos (Davis 1985). Although, in a preliminary experiment (unpublished) we saw a $27 \%$ development to blastocysts of 1- and 2cell embryos using the same media and we considered that this was a good starting point for testing the effect of oviduct cells. Addi- 
tionally, it has been found that certain batches of BSA contain low molecular weight components that promote embryonic development (Kane 1985) and it is possible that the BSA, known to vary from batch to batch, was lacking in such.

Embryos from certain donors have a better in vitro development potential than others. Since only 4 donors contributed 1-2-cell embryos for the study this effect cannot be ignored.

In conclusion, while we found a beneficial effect of oviductal co-culture upon development of 4- to 16-cell embryos with respect to embryonic cell proliferation but not developmental rate, we could not detect a similar benefit for the culture of earlier stages.

\section{Acknowledgements}

This study was supported by the Animal Biotechnology Research Center.

\section{References}

Archibong AE, Petters RM, Johnson BH: Development of porcine embryos from one-cell and two-cell stages to blastocysts in culture medium supplemented with porcine oviductal fluid. Biol. Reprod. 1989, 41, 1076-1083.

Bavister BD: Role of oviductal secretions in embryonic growth in vivo and in vitro. Theriogenology 1988, 29, 143-154.

Davis DL: Culture and storage of pig embryos. J. Reprod. Fert. 1985, suppl. 33, 115-124.

Ellington JE, Farrel PB, Simkin ME, Foote RH, Goldman EE, McGrath AB: Development and survival after transfer of cow embryos cultured from 1-2-cells to morulae or blastocysts in rabbit oviducts or in a simple medium with bovine oviduct cells. J. Reprod. Fert. 1990, 89, 293-299.

Eyestone WH, First NL: Co-culture of early cattle embryos to the blastocyst stage with oviductal tissue or in conditioned medium. J. Reprod. Fert. 1989, 85, 715-720.

Gandolfi $F$, Moor RM: Stimulation of early embryonic development in the sheep by coculture with oviduct epithelial cells. J. Reprod. Fert. 1987, 81, 23-28.
Gandolfi F, Tiziana A, Brevini L, Richardson L, Brown CR, Moor RM: Characterization of proteins secreted by sheep oviduct epithelial cells and their function in embryonic development. Develop. Biol. 1989, 106, 303-312.

Kane MT: A low molecular weight extract of bovine serum albumin stimulates rabbit blastocyst cell division and expansion in vitro. J. Reprod. Fert. 1985, 73, 147-150.

Kooyman DL, Baumgartner AP, Pinkert CA: In vitro cultivation of 1-cell and 2-cell porcine zygotes. J. Anim. Sci. Suppl. 1, 1988, 66, 422.

Krishner RL, Petters RM, Johnson BH: Effect of oviductal condition on the development of onecell porcine embryos in mouse or rat oviducts maintained in organ culture. Theriogenology 1989a, 32, 885-892.

Krishner RL, Petters RM, Johnson BH, Bavister $B D$, Archibong AE: Development of porcine embryos from the one-cell stage to blastocyst in mouse oviducts maintained in organ culture. $\mathrm{J}$. Exper. Zool. 1989b, 249, 235-239.

Menino AR jr., Archibong AE, Li JR; Stormshak F, England $D C$ : In vitro development of swine embryos collected from first and third estrous gilts. J. Anim. Sci. Suppl. 1, 1987, 79, 517.

Pinkert CA, Kooyman DL, Baumgartner A, Keisler $D H$ : In vitro development of zygotes from superovulated prepuberal and mature gilts. J. Reprod. Fert. 1989, 87, 63-66.

Pope WF, Wilde $M H$, Xie S: Effect of electrocautery of nonovulated day 1 follicles on subsequent morphological variation among day 11 porcine embryos. Biol. Reprod. 1988, 39, 882-887.

Pursel VG, Wall RJ, Rexroad CE jr., Hammer RE, Brinster RL: A rapid whole-mount staining procedure for nuclei of mammalian embryos. Therio. 1985, 24, 687-691.

Rexroad CE, Powell AM: Co-culture of ovine ova with oviductal cells in medium 199. J. Anim. Sci. 1988, 66, 947-953.

SAS Institute Inc: SAS/STAT ${ }^{\mathrm{TM}}$, Users Guide, Release 6.03 Edition, Cary, NC 1988.

White KL; Hehnke K, Rickords LF; Southern LL; Thompson DL jr., Wood TC: Early embryonic development in vitro by coculture with oviductal epithelium cells in pigs. Biol. Reprod. 1989, 41, 425-430.

Whitten WK, Biggers JD: Complete development in vitro of the pre-implantation stages of the mouse in a simple chemically defined media. J. Reprod. Fert. 1968, 17, 399-401. 


\section{Sammendrag}

Dyrkning af tidlige svineembryoner med ovidukt epithel celler.

Svineembryoner af udviklingsgraderne 1-16 cellestadier blev dyrket enten i Whittens medium tilsat bovint serumalbumin og føtalt kalveserum (WM) eller $\mathrm{i}$ det samme medium med svine ovidukt epithelceller (WM-POEC). Efter dyrkning i 144168 timer havde embryoner af alle udviklingsstadier højere celletal i WM-POEC end i WM. Der var dog ingen signifikant forskel i blastocyst raten mellem de to grupper. En høj andel af de embryoner, der begyndte som 1-2 cellestadier var i stand til at passere 4-celle-blokket i WM (81\%) og i WMPOEC (77\%). I begge medier standsede de fleste af disse deres udvikling ved kompakt morula stadiet, mens de embryoner, der påbegyndte deres dyrkning som 4-8-16 celle stadier for størstepartens vedkommende (80-90\%) udviklede sig til blastocyster.

(Received April 22, 1992; accepted June 26, 1992).

Reprints may be requested from: S. Smith, Department of Clinical Studies, Reproduction, Royal Veterinary and Agricultural University, Bülowsvej 13, DK-1870 Frederiksberg C, Denmark. 